\title{
Changes in and the Maturation of the Science of Education in Lithuania
}

\author{
Ona Tijūnèlienè
}

\begin{abstract}
Afer 1990, trends, changes, and maturation of the Lithuanian science of education were affected by the reforms in the system of education and the ideas of lifelong learning. This research focuses on the changes and the development of the science of education in Lithuania from 1992 to 2004 . The purpose of the study is to identify the attributes of change and development of the science of education by addressing the following: the concept of the science of education and changes in terminology and and the conception of the object and structure of research. The methods include historical-descriptive, partial comparison, analysis, and synthesis. The term 'pedagogy' was found to be too narrow to define the improvement of learning throughout a lifetime. Therefore, the term justified by Leonas Jovaiša, educology, was established: educology was considered a science that investigated permanently the education of individuals and groups. The creators of the science of education at the time included Leonas Jovaiša (1921-2017), Bronislovas Bitinas, Vanda Aramavičiūte, Palmira Jucevičiene, and Juozas Vaitkevičius (1928-2002). Jovaiša considered pedagogy to be the nucleus of the science of educology; however, he also identified other branches. Moreover, he developed the concept of humans' long-life improvement. He defined educatonal reality as a totality of "finite educational events improving an individual," discrete and continuous. The indispensable conditions were the meeting of subjects and their disposition towards and openness to information and its exchange. Bitinas identified elements of educational reality and defined their relationships and characteristics. He noted that the object of educology was a cluster of education problems without strict boundaries. Educology also dealt with other sciences.
\end{abstract}

Keywords: educational science, educology, pedagogy, research object in the science of education

\section{Introduction}

After the restoration of Lithuania's independence in 1990, trends, transformations, and maturation of the science of education was affected by the rebuilding of the Lithuanian system of education on new foundations. The development of new models of education reform was related to $21^{\text {st }}$ century expectations and oriented towards the educational experience of the democratic world. The drafting of "new era" documents was based on the provisions affecting the science of education: a) the individual's training at school was a cultural process; b) it was important to seek harmony of all levels of education and to ensure diverse educational integration; c) a holistic approach to the process of education and individuals were of the utmost importance; 
d) knowledge conveyance was to be combined with the development of personal abilities and of moral and emotional culture; and e) the principal objectives of the individual's general education were to be related to fostering of competences necessary for life and professional activity. ${ }^{1}$ Lithuanian scholars were able to resume traditions developed before 1940: "Lithuanian pedagogy and school were, and remained, enlightened and academic. That was the European, and especially German, influence. ... all academic studies of the time were based on experimental data obtained by investigating the situation at school and in life practice." ${ }^{2}$ Some influence also came from external factors due to the spread of the idea of lifelong learning of knowledge societies in Western countries, pursuing a new type of quality, and the findings of the latest research. ${ }^{3}$

Through their research, Lithuanian scholars sought to help practicing teachers better understand the process of education, its object, and its structure, as well as to master the functions of their activities. Leonas Jovaiša created a genetic system (theory) of the goals of integral education, identified the branches of educational science, justified a new definition of the science of education, and defined the structure of education. ${ }^{4}$ Bronius Bitinas studied the structure of the object of the science of education, published studies devoted to the epistemology of educational reality, and laid the foundation for interdisciplinary educational research. ${ }^{5}$ Vanda Aramavičiūte focused on the concepts of education, its homegeneity and integrity, and compared the positions of Lithuanian and Western scholars. ${ }^{6}$ Meile Lukšiene wrote about the education of human beings in cultural contexts and human culture. ${ }^{7}$ Marija Barkauskaite investigated the science of education, ${ }^{8}$ as did Elvyda Martišauskiené $\dot{e}^{9}$ and others.

This research focuses on the changes and the maturity of the science of education in Lithuania from 1992 to 2004. The purpose is to identify the attributes of the changes and the maturity of the science of education,

1 Ž. Jackūnas, Lietuvos švietimo kaitos linkmès [Lithuanian educational change convergent], Vilnius, Kultūros, filosofijos ir meno institutas, 2006, pp. 6-8.

2 J. Vaitkevičius, Lietuvos pedagogika ir mokykla istorijos vingiuose [Lithuanian pedagogy and school history bends], Šiauliai, Vṣ̌ Šiaulių universiteto leidykla, 2008, p. 61.

3 P. Jucevičiené, Ugdymo mokslo raida: nuo pedagogikos iki šiuolaikinès edukologijos [Educational scientific developments from pedagogy to contemporary science of education], Kaunas, Technologija, 1997, pp. 11-15.

4 L. Jovaiša, Edukologijos ịvadas [Introduction of educology], Kaunas, Technologija, 1993.

5 B. Bitinas, Ugdymo tyrimy metodologija [Educational research methodology], Vilnius, Jošara, 1998; B. Bitinas, Ugdymo filosofija [Philosophy of education], Vilnius, Enciklopedija, 2000.

6 V. Aramavičiūte, Ugdymo samprata [Concept of education], Vilnius, Vilniaus universiteto leidykla, 1998.

7 M. Lukšienè, Jungtys [Connections], Vilnius, Alma Littera, 2000.

8 M. Barkauskaité, 'Profesoriaus Bronislovo Bitino moksliniu idejų sklaida edukologijos moksle' [Dissemination of the scientific ideas of professor Bronislovas Bitinas in the science of education], Pedagogika [Pedagogy], no. 4, 2016, pp. 9-15.

9 V. Aramavičiūtè, E. Martišauskienè, 'Ugdymo gelmiu paieška Bronislovo Bitino pedagoginès minties lobyne' [Search for the depths of education in the treasury of B. Bitinas' pedagogical thought], Pedagogika [Pedagogy], no. 4, 2016, pp. 16-27. 
addressing the following issues: the concept of the science of education and changes in terminology and concepts of the object and the structure of research on the science of education. I used historical descriptive, partial comparison, analysis, synthesis, generalisation, and abstraction methods. The research methodology was based on the following considerations. 1) Since the $19^{\text {th }}$ century, philosophical hermeneutics has been trying to indicate the historical gap between the interpreter and the interpreted subject and to reveal respective meanings and ideas in the social and temporal context in which they were born. ${ }^{10}$ 2) Jovaiša defined science as a system of empirically and theoretically verified and justified knowledge about an area of reality or the universe. Science also implied the activity through which new objective and systematised results of the reality cognition were obtained. The science of education reflected pedagogical reality and contributed to its improvement. ${ }^{11}$ 3) In modern times, scientific theories and basic scientific arguments were explained as unavoidably hypothetical. In any area of science, the principal ideas about its research object changed in the process of history, as did the understanding of knowledge and science. ${ }^{12}$ Scientific development research criteria included the terms and concepts of the science of education and formal establishment of a scientific discipline: the characteristics of establishment (rationality, reliability, fundamentality and applicability, and institutionalisation) and the status of the discipline (a clear object of study, its prospects, object stucturisation techniques, etc.). ${ }^{13}$

Due to the limited scope of the paper, the works of Leonas Jovaiša and Bronius Bitinas, who made the greatest contributions to the science of education during the transformation period between dicatorship and democracy, were chosen.

\section{Nature and terminology of the science of education}

As noted by Jovaiša, education is the most important "law" of the universality evolution, as everything that exists changes and shapes one another and takes out of the state of chaos. The shape of all becomes more perfect. This interdependence can be justified by laws of interaction. ${ }^{14}$ Jovaiša makes humans stand out among other creatures as self-educating beings and calls self-education an innate matter. It is due to the innate spring of self-education (the rudiment of self-education) that makes humans sensitive and susceptible to environmental influences, providing them with a wide range of information.

\footnotetext{
10 A. Halder, Filosofijos žodynas [Dictionary of philosophy], Vilnius, Alma Littera, 2002, p. 84.

${ }^{11}$ L. Jovaiša, Enciklopedinis edukologijos žodynas [Encyclopedic dictionary fo educology], Vilnius, Gimtasis žodis, 2007, pp. 170-171.

12 A. Halder, Filosofijos žodynas [Dictionary of philosophy], Vilnius, Alma Littera, 2002, p. 84.

${ }^{13}$ P. Jucevičienè, Ugdymo mokslo raida: nuo pedagogikos iki šiuolaikinès edukologijos [Educational scientific developments from pedagogy to contemporary educology], Kaunas, Technologija, 1997, pp. 11-15.

${ }^{14}$ L. Jovaiša, Edukologijos įvadas [Introduction of educology], Kaunas, Technologija, 1993, p. 5.
} 
The information leads to responses (intellectual, emotional, of willpower, etc.) and as if "takes" man out of a closed inner life into an open-to-the-world system. He notes that the Latin word 'educare' best expresses the purpose of educology: the science of how to take humans out into this complex world, ${ }^{15}$ so as to make them more perfect creatures. Self-educating humans remain spontaneous and creative through acquaintanceship with the spiritual (or intellectual) treasures of the world. Human nature is harmed by inappropriate education. People become more perfect when they develop the power of creation that brings them closer to "the essential principle of Universality, i.e. creation." ${ }^{16}$ Thus, education is meant not only to introduce humans to the world, but it also enables them to create and to exploit all the possibilities of individual self-realisation.

Jovaiša saw the factors for the emergence of the term of 'educology' in the early $19^{\text {th }}$ century, when Robert Owen (1771-1858) started training adults in Scotland. Adult education spread to Russia and to other countries. Articles on adult pedagogy began appearing. Johann Friedrich Herbart (1776-1841) named adult pedagogy 'andragogy'. In June 1965, experts meeting at UNESCO headquarters concluded that progress in all areas of life required a type of education that would last an entire working life ('permanent' in French and 'lifelong' in English). In Western countries, new ideas on the improvement of pedagogy of continuing education appeared. It became clear that the term 'pedagogy' was inappropriate for permanent human education as the object of permanent human education was an individual or groups of individuals of different ages, and the subject (problem) was the education of the individual or a group of individuals.

Jovaiša emphasised the role of the individual in the pursuit of perfection: improvement was predetermined not by education, as the actions of education meant only the provision of an individual by means of self-expression (an obligatory condition of self-expression). Improvement was predetermined by the self-educating nature of humans and their spiritual disposition. An appropriate base of education could give humans fullness of life. Since life was an intimate human interaction with the environment in which human nature was revealed, this represented the essence of education: “...through the intimate life of child, youth, and adult to create a higher outer and inner life ... Thus education covered the management of daily living which enabled an individual to independently seek a higher physical and spiritual life corresponding to the ideals of family, nation, and society." ${ }^{17}$ Education was the "creation of a fulfilling human life by one's own powers through providing one with the means of self-expression."18

Jovaiša rationally and logically justified the concept of becoming a fullfledged human being. He identified the areas of life in which the outer and

\footnotetext{
${ }^{15}$ L. Jovaiša, Edukologijos įvadas [Introduction of educology], Kaunas, Technologija, 1993, p. 5.

16 Ibid.

${ }^{17}$ Ibid., p. 10.

${ }^{18}$ Ibid.
} 
inner human life took place: natural, existential, practical, economic, social, cultural, psychological, and spiritual. ${ }^{19}$ Next to the areas of life, Table 1 indicates the essentials of life and the functions of education which made up close unity and clearly demonstrated the opportunities of individual holistic education.

Table 1. The essentials of life and the functions of education

\begin{tabular}{|c|l|l|l|l|l|}
\hline \multirow{2}{*}{ No. } & \multirow{2}{*}{$\begin{array}{c}\text { Areas of } \\
\text { life }\end{array}$} & \multicolumn{1}{|c|}{ Mind } & \multicolumn{1}{|c|}{ Creation } & \multicolumn{1}{|c|}{$\begin{array}{c}\text { Munctions of } \\
\text { education }\end{array}$} \\
\cline { 3 - 5 } & Natural & Activity & $\begin{array}{l}\text { Independent } \\
\text { action }\end{array}$ & Sensitivity & Enabling \\
\hline 2 & Existential & Information & Self-expression & Safety & $\begin{array}{l}\text { Care and } \\
\text { provision }\end{array}$ \\
\hline 3 & Praxial & Learning & Game & Work & Teaching \\
\hline 4 & Economic & Competences & Organisation & Profit & Development \\
\hline 5 & Social & Communication & Relations & Concord & Upbringing \\
\hline 6 & Cultural & Science & $\begin{array}{l}\text { Arts and } \\
\text { technology }\end{array}$ & Customs & Education \\
\hline 7 & Mental & Cognition & Emotions & Willpower & Training \\
\hline 8 & Spiritual & Truth and faith & Beauty and hope & $\begin{array}{l}\text { Good and } \\
\text { love }\end{array}$ & Formation \\
\hline
\end{tabular}

The in-depth relations between those matters were best described by Jovaiša: "The merging of the essentials of life into a single framework provides the creation of a fulfilling life and the conditions for cultural and spiritual self-expression ... The functions of education are complementarily interrelated: the closest relations, arising from enabling, exist between teaching and training, between care and upbringing; formation covers qualitative improvement of innate human properties; it manifests itself in each function of education." ${ }^{20}$ This allowed Jovaiša to formulate the definition of functional education: "Education means the enabling of man or a group of people that forms their new characteristics in the process of education, teaching, development and training, provision, care, and upbringing." ${ }^{21}$

Jovaiša explained that education covered all areas of life and was permanent. The science of pedagogy claimed all those areas, but it was restricted to the science of children and youth education. The term was inappropriate to define the education of people of all ages and to express the reality of education. The science of education covered the entire human life, requiring a new term, 'educology': "Educology is the science of studying permanent education of an individual or their groups." ${ }^{2}$ The definition was justified through identification

\footnotetext{
${ }^{19}$ L. Jovaiša, Edukologijos ịvadas [Introduction of educology], Kaunas, Technologija, 1993, p. 13.

${ }^{20}$ Ibid.

${ }^{21}$ Ibid., p. 13.

${ }^{22}$ Ibid., p. 14.
} 
of the branches of educology: a) familistics - the science of family, covering its educational functions; b) pedagogy (theoretical-general, didactic, hodegetics); pre-school (creche and kindergarten); school (general education, vocational, for children with special needs); c) social educology - adult (andragogy, retraining, professional development); community (protection/care, social management, counselling); local environment (leisure, parallel, alternative/open door; youth groups and organisations, progress schools); d) cultural educology (mass media, ethnological, religious, art institutions); e) subculture educology - delinquent (prevention, rehabilitation) and penitentiary (youth and adult). Jovaiša predicted the viability of those structures of science only if the successes of an appropriate educational policy and organisation could be predetermined by a contemporary science of management: "Education management has to become a central tool in the implementation of the ideas, programmes, and methods of educology because it covers issues of organisation and management of the structures of education, management of institutional activities, regulation of actors' relations, economy, and management of youth and adults."23

Thus, the term 'educology' was established in Lithuanian terminology in the 1990s. Its equivalents in English are education or educational science and in German - Erziehungwissenschaft. The more precise definition of permanent education was used in Poland and other countries. ${ }^{24}$

Jucevičiene published several works abroad on the establisment of the term educology in the Lithuanian science of education. ${ }^{25}$ She justified the viability of the term by use of the word in publications in English: it could be found in documents of the Conference of the Research Network on Education held in Stockholm in 1996, in conference documents of the Network of Educational Science (NESA) in Amsterdam, and in several publications. ${ }^{26}$

To conclude, Jovaiša contributed to the development of the science of education and the establishment of a new term. He related the nature of education to intrinsic human powers - spiritual, physical, and intellectual - and justified the importance of their permanent improvement at different ages, as well as identifying the branches of the science of educology that corresponded to various age levels. Jovaiša created a rational, reliable, and fundamental theory of education in which he rationalised the opportunity for each individual to improve their inner and outer lives - to interact with all areas of life, to receive information, and to create a fulfilling life through the means of self-expression. The theory provided logical justification for the fact that the merging of the essentials of life into a single framework ensured creation of a fulfilling life

\footnotetext{
${ }^{23}$ L. Jovaiša, Edukologijos ịvadas [Introduction of educology], Kaunas, Technologija, 1993, p. 15.

${ }^{24}$ Ibid., p. 9.

${ }^{25}$ P. Jucevičiene, 'From Pedagogy to Educational Science, from Western Europe to Lithuania and from Lithuania to Western Europe', in Ch. Wulf (ed.) Education in Europe. An An International Task, Münster/New York, Wachman, 1995, pp. 149-154.

${ }^{26}$ P. Jucevičiené, Ugdymo mokslo raida: nuo pedagogikos iki šiuolaikinès edukologijos [Educational scientific developments from pedagogy to contemporary educology], Kaunas, Technologija, p. 20.
} 
and conditions for cultural and spiritual self-expression, while the qualitative improvement of the characteristics of human nature manifested itself in each function of education. Jovaiša's theory of education was significant for the development of research and the practice of education.

\section{The object of the science of education and its structure}

As emphasised by Jovaiša, one of the key objectives of epistemology was the identification of the researched scientific object. The author defined it as educational reality, i.e. the process in which personality continuously matured, and explained it as a special phenomenon, described its development, and identified the structural components and specific attributes. He also discussed the possibility of seeing and observing it with the aim of empirical research. To start with, education happens when educator and learner meet. The 'meeting' is an indispensable condition for the 'educational event' to happen; the event results in spiritual and physical changes in an individual. He defined the meeting as a finite, yet recurring act consisting of a certain definite number of events. However, when watching from the side, it is impossible to establish whether all the events are educational as one can see only the external picture of the event while the internal one remains hidden. Education takes place only in the case when internal events promote changes in an individual. Therefore, the probability of coincidence of external and internal events is never clear until special research is carried out. ${ }^{27}$ Educational reality is defined by Jovaiša as a discrete, discontinuous, and processual - "a totality of educational events improving an individual."28

Typically for educational reality, an event is 'a process of interaction', and it has internal content and meaning, not merely a visible external picture. The content of the event consists of a quantity (quantum) of information that is wealth. In the process of an educational act, epistemic, practical, technological, and evaluative information reveals itself: the source of the first is science; of the second, the way of evaluation; and of the third, the value of action, philosophy, and morals. All that wealth becomes objective only when it acquires social significance. It can direct human activity in one or another way. Therefore, an event as a component of the reality of education is always concise and meaningful and has specific educational value. ${ }^{29}$

A meaningful characteristic, which does not, however, predetermine the character of educational reality, is the fact that education takes place in space and time. Its space (structure) is a microenvironment (family, group, class, another group), macroenvironment (society, its culture, the whole world), and meta-environment (spiritual values). All types of environment are limited

\footnotetext{
${ }^{27}$ L. Jovaiša, Edukologijos ịvadas [Introduction of educology], Kaunas, Technologija, 1993, p. 150.

${ }^{28}$ Ibid.

${ }^{29}$ Ibid., pp. 148-149.
} 
by geographical, cultural, and national contexts. The time of the educational process is also limited by an epoch or the duration of intensive education or human life. Time and space affect the quantity and quality of educational information.

Educational reality is characterised by a specific change of events. Jovaiša indicates the conditions that define that specificity and that are necessary for education to take place: educational meeting of subjects; disposition and openness to information; and exchange of information. Other conditions predetermining educational events include specific material, objective and cultural, biological and social 'situation of events', and a general spiritual 'atmosphere' of events. ${ }^{30}$

Jovaiša attached great value to the educational meeting of subjects in which educational interactions and individual relations begin: subject subject and subject - object relations (knowledge, ideas, thoughts, and ideals). They predetermine the value of the content and the character of the participants' meeting. The quality of relations depends on the innate and acquired characteristics of the subject (temperament, abilities, intellect, emotions, experience and knowledge, attitudes, interest, stable and situational motivation, preconceptions, etc.). The value of the meeting depends especially on the specific emotional state invoked and afterwards, the intellectual state. The latter regulates the quality of the emotional state and its value for spiritual activity; positive emotions remove subconscious barriers to productive educational impacts. Emotions present a principal condition for succesful education; therefore, the teacher's first objective is to evoke and maintain learners' positive emotions to boost their self-confidence. An educational event, i.e. the exchange of educational information, will never take place in the case of deformed communication. ${ }^{31}$

As noted by Jovaiša, the exchange of information is impossible in the case of 'subject-object' relations as the learner will get one-directional information. However, efficiency of information perception, processing, and response depends on the state of emotions, the data of the intellect, and efforts of willpower (from psychophysical disposition and spiritual openness to wealth): "...psychophysical tension is necessary; otherwise, no efficient mastering will happen ... The combination of tension and relaxation is unavoidable." ${ }^{32}$ As the learner receives information from living people, they can also exchange information - experiences, emotions, ideas, and thoughts. In such cases, the intellect of the interacting participants is developed, emotions are corrected, and comprehensive maturity of personality takes place. Jovaiša exalts the role of educator, as nobody can replace him. ${ }^{33}$

\footnotetext{
${ }^{30}$ L. Jovaiša, Edukologijos įvadas [Introduction of educology], Kaunas, Technologija, 1993, p. 151.

${ }^{31}$ Ibid.

${ }^{32}$ Ibid., p. 152.

${ }^{33}$ Ibid.
} 
Another condition of the process is a 'situation.' One kind of situation happens when learners use immaculate or disorderly aids: they learn in one way when faced with too difficult tasks and in another when faced with too easy tasks.

Great significance is attached to spiritual events. Optimal pedagogical interaction requires a common spiritual elevation of subjects: "The spiritual atmosphere is not merely an inclination or a psychological climate; it is characterised by overstepping the daily concerns or individual existential needs and elevation to a higher world, to the area of cultural and spiritual values in which an individual shall immerse, detached from the daily routine. Such a transcendental state of a pedagogical meeting is an ideal condition for the emergence of educational events." ${ }^{4}$

In the structure of educational reality, Jovaiša identified the techniques, which caused educational events to happen and the different ways educational information is transferred and received.

As summarised by Jovaiša, educational reality consisted of 1) an educational informative event, 2) a material and spiritual environment, 3) the conditions of education, and 4) aids, techniques, and methods. "To get to know it, one needs to investigate all those components." ${ }^{35}$ Its description proved that the educational process had internal and external, or subjective and objective, parts.

To conclude, Jovaiša contributed to changes in the science of education and its status: he clearly defined the research object (educational reality), structurised it logically, described the in-depth relations of the external and internal (objective and subjective) parts, and identified the criterion for the identification of an educational event - personal improvement. He also emphasised the role of relations and emotions for the emergence of an optimal pedagogical interaction and created the opportunities for promising scientific research.

The concept of the research object in the science of education was enriched with innovative ideas by Bronius Bitinas. He believed that each science looked for its object in a specific reality by abstracting from some of the attributes of that reality: "Thus, the object of the science shall not be identified with the reality. Therefore, the classical statement that pedagogy is a science about education is not precise from the viewpoint of the contemporary theory of scientific cognition: education is a reality open to a number of sciences, while the science of educology deals with one (essential) aspect of education." ${ }^{36}$ In the reality of education, Bitinas identified five levels:

1) Societarian level whose essence it is to create the conditions necessary for the education of the society members. Legal regulation is especially important;

\footnotetext{
${ }^{34}$ L. Jovaiša, Edukologijos įvadas [Introduction of educology], Kaunas, Technologija, 1993, p. 152.

${ }^{35}$ Ibid., p. 158.

${ }^{36}$ B. Bitinas, 'Apie edukologijos mokslo objektą' [On the object of educology science], Socialiniai mokslai: Edukologija [Social Sciences: Educology], vol. 1, no. 5, 1996, p. 54.
} 
2) Social educological level, which is the functioning of institutions necessary for education. It is important to create a system of education in which all the institutions carry out a public commission in close cooperation;

3) Institutional level whose most important aspect is organisational. This means each institution is regarded as an organisation seeking to optimise the activity of the participants in the education process. Successful education is a precondition for the improvement of society;

4) Interpersonal level, which deals with the interaction of educator and learners. Its content consists of flows of educational information. First, the conveyance of information summarised by humanity to learners, and second -feedback. The flows create an educational environment that leads to the optimisation of the learners' self-evolution; and

5) Intrapersonal level in which educational interaction is understood as the individual's self-improvement. Self-improvement acquires its pure shape only at the specific level, which characterises the efficiency of all levels.

Bitinas formulated the criteria for recognition of educator and learner and revealed which interpersonal interactions were to be attached to the sphere of education and how education was related to other spheres of spiritual existence. Contemporary conceptions of education were based on an assumption that each individual educated him or herself and improved throughout life, so she/he remained the object (and the subject) of education throughout all the stages. All pedagogues of educational institutions and sports coaches belonged to the sphere of education, and educational functions were performed by families, mass media, and the arts. Education was organised also by imprisonment institutions, psychological services, etc. The number of the educational interaction participants was not limited, but a positive goal for the activity was a must: "...individuals' interactions were educational when one person by her/his activity sought to improve the personalities of other individuals." ${ }^{37}$

Bitinas disclosed how educational interaction manifested itself: in practice, it was recorded as 'an event', 'a pedagogical meeting', or 'an act of education.' To be able to call an act an educational phenomenon, it had to repeat. As the interaction was individual, its essence and what was invariant had to repeat. That proved that education was not a pure phenomenon; it was an outcome of cognitive activity. The phenomenon could be investigated and described, and the factors predetermining it could be established.

In educational reality, Bitinas held educational processes to be of the greatest importance: "Structurally the process is a purposeful sequence of the states of the educational interaction." 38 The process was always purposeful; it was a self-regulating system. Therefore, the educator, as a participant of the process,

\footnotetext{
${ }^{37}$ B. Bitinas, 'Apie edukologijos mokslo objektą' [On the object of educology science], Socialiniai mokslai: Edukologija [Social Sciences: Educology], vol. 1, no. 5, 1996, p. 54.

38 Ibid., p. 55.
} 
regulated the improvement of learners inside the system. That defined the closed nature of the system. Moreover, Bitinas characterised the educational process as stochastic and hierarchical: stochasticity was the probability of relations of the educational process components and hierarchy meant that "in the structure of education, the higher level was the probabilistic outcome of the functioning of the lower level, while the lower level was the condition of the functioning of the higher level, i.e. the relation between the educational levels was not linear." ${ }^{39}$ Those characteristics meant that the educational process was weak: it was not a stable system. The system could be deformed by side effects and turn its development in a direction harmful to the personality. Outcomes of such processes could be predicted only stochastically: "This characteristic of the educational process is preconditioned by its nature." 40

Bitinas considered the aims and the content of education to be the most important components of educational interaction. The nature of information in the educational process and its impact on personality self-development depended on them. The aims and the content of education could only be perceived by knowing the concept of education as the relation between educational information and the processual aspect of education could be explained as the relation of the content and the form; both made up a totality. "Educational information is a dynamic and constantly changing aspect of education, while the processual structure defines a system of sustainable relations of the educational reality." 41 Thus, "educational phenomena and processes make up the nucleus of the object of the sciences of educology." 42

As Bitinas explained, there was a periphery around the nucleus of the object -the problems of education. Along with educology, they were dealt with by other sciences of education such as the philosophy, physiology, psychology, sociology, ethnology, demography, politics, economics, management, and history of education. Therefore, the object of the science of educology was a cluster of educational problems with no strict boundaries: "Due to such openness, one can more comprehensively get to know educational reality, i.e. to more perfectly design, create, and manage it." ${ }^{33}$ Bitinas was the first in Lithuania to justify the opportunities of multidisplinary research on education and to implement the idea: he wrote the Philosophy of Education, which focused on the epistemological aspect of educational reality. ${ }^{44}$

To conclude, Bitinas expanded and enriched the concept of the object in the science of education: he defined the components of educational interaction, the criteria for the recognition of educator and learner, identified the characteristics of the educational process, and justified the unity of

\footnotetext{
${ }^{39}$ B. Bitinas, 'Apie edukologijos mokslo objektą' [On the object of educology science], Socialiniai mokslai: Edukologija [Social Sciences: Educology], vol. 1, no. 5, 1996, p 55.

40 Ibid.

41 Ibid.

42 Ibid.

${ }^{43}$ Ibid.

${ }^{44}$ B. Bitinas, Ugdymo filosofija [Philosophy of education], Vilnius, Enciklopedija, 2000.
} 
the content of education and the processual aspect, as well as the nucleus of the science of educology and the periphery of the object around it, i.e. the cluster of education problems having no strict boundaries, thus, he opened up an opportunity for new fields of research in Lithuania and for multidisciplinary research of education problems. Bitinas' ideas are basic and formulated at a high level of abstraction, most frequently of philosophy. The significance of Bitinas' research was shown through the dissemination of his ideas in the global scientific community. In Thomson Reuters Web of Science Cited Reference Search, he was cited 56 times, as well as in the Scopus database, while in the Lituanistika database, he was cited 923 times from 2000-2013. ${ }^{45}$

\section{Conclusion}

The changes in the science of education and its maturation in Lithuania from 1992-2004 were proved by the following:

1) The development of the nature/concept of the science of education, predetermined by the idea of permanent learning and its implementation. The term 'pedagogy' became too narrow to define educational reality. The new term of 'educology' was justified. The nature (concept) of the science of education was related to discontinuous improvement of innate human powers, and the branches of the science of education corresponding to age stages were justified.

2) A unique, basic conception of improvement of the inner and outer human life was created, in which, based on the principles of integrity and systematicity, the following components were merged into a homogeneous foundation: areas of life (where all the human life, both inner and outer, took place) with which man interacted and acquired the opportunity to improve; the foundations of life (mind, creation, morals); and the functions of education. As demonstrated by the concept, education ensured continuous improvement of innate human characteristics corresponding to human nature as integral beings and their function as creators.

3) A clear and promising research object was defined and logically structurised; the in-depth relations of the external and internal (objective and subjective) parts of the educational process with their own microstructures were identified; a criterion for the cognition of an educational 'event', i.e., personal improvement was established; and the role of relations and emotions for the emergence of an optimal pedagogical interaction was disclosed.

4) The criteria for recognition of educational interaction, educators, and learners were formulated in a scientifically-justified way, the relationship

\footnotetext{
${ }^{45}$ M. Barkauskaite, 'Profesoriaus Bronislovo Bitino mokslinių ideju sklaida edukologijos moksle' [Dissemination of the scientific ideas of professor Bronislovas Bitinas in the science of education], Pedagogika [Pedagogy], no. 4, 2016, pp. 9-15.
} 
between education and other spheres of spiritual existence were established; characteristics of the educational process, the purposeful sequence of the states of the educational interaction as a self-regulating system were identified (purposefulness, a closed nature, stochasticity, hierarchy, instabilility, and the outcome probability). The nucleus of the sciences of educology, i.e. the phenomena and objects of education, was established, as well as the periphery of the object around the nucleus, e.g., a cluster of problems without strict boundaries that opened up to integrate the opportunities of different sciences in the investigation of education problems. Moreover, the concept of education was specified: education was a reality open to a number of siences, while the science of educology dealt with one essential aspect of education. The characteristics of institutionalisation of the above-discussed ideas of the science of education in Lithuania are the following: rationality, reliability, fundamentality, and applicability. 